Beata Katarzyna Jędryka

Uniwersytet Warszawski

e-mail: beata.jedryka@gmail.com

ORCID: 0000-0002-1446-8910

\title{
O POTRZEBIE BADANIA KOMPETENCJI LEKSYKALNEJ DZIECI W WIEKU WCZESNOSZKOLNYM W DYDAKTYCE JĘZYKA POLSKIEGO ZA GRANICA (NA PRZYKLADZIE STANÓW ZJEDNOCZONYCH I UKRAINY)
}

\section{WPROWADZENIE}

Współczesna glottodydaktyka polonistyczna jeszcze w pierwszym dziesięcioleciu XXI wieku koncentrowała się przede wszystkim na dorosłych użytkownikach języka polskiego jako obcego. Nieliczni językoznawcy podejmowali się prowadzenia badań stricte lingwistycznych wśród młodzieży posługującej się polszczyzna poza granicami Polski, a analizy języka dzieci należały do rzadkości. Sytuacja ta uległa zmianie $^{1}$ i została dostrzeżona przez środowisko akademickie, choć nadal jest przedstawiana jako coś nowego, określanego mianem innowacji glottodydaktycznej [Miodunka 2016]. Mimo wszystko w porównaniu z nurtami badań podejmowanych w obszarze innych języków, nawet tych o mniejszym znaczeniu na mapie politycznej świata, jak np. język koreański czy grecki, glottodydaktyka polonistyczna plasuje się na końcu, jeżeli mamy na uwadze opisy języka polskiego, którym komunikuja się dzieci poza Polską.

Znikomą obecność języka dzieci w badaniach o charakterze lingwistycznym można tłumaczyć głównie tym, że zaplanowanie i przeprowadzenie samej procedury zbierania danych językowych w tej grupie respondentów jest utrudnione. Wymaga od badacza nie tylko wiedzy $z$ różnych zakresów, ale także dostępu do samych dzieci spełniających kryteria badawcze. Oczywiście prowadzone sa badania z zakresu psycholingwistyki czy logopedii wśród najmłodszych użytkowników polszczyzny w różnych uwarunkowaniach środowiskowych, jednak mają one

1 Po 2005 roku ukazało się kilka opracowań dotyczacych polszczyzny dzieci i młodzieży poza granicami Polski takich autorów jak: J. Cieszyńska, A. Czeniek, K. Geben, B.K. Jędryka, K. Kuros-Kowalska, R. Laskowski, A. Libura, E. Lipińska, B. Maliszewski, M. Piasecka, H. Pułaczewska, A. Rabiej, A. Seretny, H. Sokołowska, N. Szumlańska, A. Żurek. Prace te można podzielić na te, które maja charakter językoznawczy, psycholingwistyczny oraz logopedyczny. 
odmienny charakter niż te, w których przedmiotem jest nie tylko język jako system składający się $z$ mniejszych elementów (np. fleksja, składnia czy leksyka), ale także narzędzie zdobywania wiedzy o świecie.

Problemy $z$ pozyskaniem materiału językowego wynikaja przede wszystkim $z$ wieku respondentów, który ma istotny wpływ na dobór metod i technik badawczych. Dzieci w wieku przedszkolnym oraz uczniów klas pierwszych można poddać próbom opierającym się wyłącznie na interakcji werbalnej, ponieważ nie dysponuja oni rozwiniętą sprawnościa czytania i pisania. Oczywiście, uczniów klas drugich oraz trzecich można testować $z$ wykorzystaniem wszystkich sprawności językowych, jednak proces zbierania danych jest żmudny, gdyż dzieci w tym wieku nie sa $\mathrm{w}$ stanie wypełniać długich ankiet lub arkuszy $\mathrm{z}$ zadaniami, co dla nastolatków oraz dorosłych nie stanowi dużego wyzwania. Dlatego też, decydując się na taka procedurę badawcza, należy dobrze ja zaplanować $\mathrm{w}$ czasie i pamiętać, że czasami $z$ respondentem trzeba spotkać się nawet cztery razy, aby uzyskać pełny obraz jego polszczyzny.

Opracowania dotyczace dzieci w wieku wczesnoszkolnym, dorastajacych w otoczeniu dwóch języków poza granicami Polski, częściej przygotowywane sa w duchu socjolingwistycznym lub psycholingwistycznym. Rzadziej spotyka się doniesienia $z$ badan, których przedmiotem jest kompleksowa analiza całego systemu lub wybranego podsystemu. W tym miejscu należy wspomnieć o pracy poświęconej polszczyźnie uczniów klas drugich oraz szóstych polskiej sobotniej szkoły dokształcającej w Stanach Zjednoczonych, w której przedstawiałam język uczniów polonijnych, analizujac wszystkie warstwy systemu: fonetykę, fleksję, słowotwórstwo, składnię oraz leksykę [Jędryka 2012]. Takich prac stanowczo brakuje, a wyniki badań językoznawczych powinny stanowić podstawę opracowywania programów nauczania oraz przygotowywania materialów dydaktycznych - podręczników, zeszytów ćwiczeń czy kart pracy dla uczniów za granica, którzy mają utrudniony kontakt $z$ rodzimymi użytkownikami języka. Dodatkowo warto po nie sięgać także podczas kształcenia nauczycieli pracujacych w szkołach, w których jest nauczany język polski - chodzi tu o szkoły sobotnie oraz dwujęzyczne.

Poznanie jakości polszczyzny jej najmłodszych użytkowników wynika przede wszystkim $z$ potrzeb edukacyjnych - nauki języka polskiego nie tylko osób o polskich korzeniach, szczególnie na Ukrainie oraz w Stanach Zjednoczonych [Karaś 2015; Jędryka 2017]. Oczywiście trzeba wspomnieć także o aspekcie tożsamościowym ważnym dla osób polskiego pochodzenia, dla których istotnym elementem życia w diasporze jest podtrzymanie tradycji i przynależności do kultury kraju przodków.

Badania poszczególnych kompetencji językowych dzieci wieku wczesnoszkolnym poza Polska, $z$ wykorzystaniem kontrastów, powinny być śmielej podejmowane przez środowisko glottodydaktyczne. Naturalnie wymagaja one nie tylko znajomości polszczyzny, ale także języka / języków kraju zamieszkania respondentów przynajmniej w stopniu średnio 
zaawansowanym. Określenie poziomu znajomości słownictwa - kompetencji leksykalnej, można uznać za pierwszy krok w praktycznym wykorzystaniu badań językoznawczych w działaniach glottodydaktycznych, które powinny podażać za trendami w dydaktyce języków drugich oraz obcych.

\section{FUNKCJE I STATUS JEZYKA POLSKIEGO POZA GRANICAMI KRAJU}

Wzrost mobilności Polaków na przełomie XX i XXI wieku, spowodowany przemianami politycznymi i ekonomicznymi, miał znaczacy wpływ na zmianę statusu polszczyzny na całym świecie. Oczywiście nie zyskała ona na popularności tak jak język chiński, angielski czy hiszpański, ale na pewno zwiększyła się liczba jej użytkowników w komunikacji, zarówno na gruncie domowym, jak i edukacyjnym oraz zawodowym. Prawdopodobnie na tę sytuację miało też wpływ upowszechnienie systemu certyfikacji znajomości języka polskiego jako obcego, który od 2003 roku stał się dostępny dla osób dorosłych, a od roku 2017 także dla dzieci i młodzieży w wieku 14-17 lat.

Mimo że język nie jest obligatoryjnym elementem pojęcia narodu [Mielczarek, Walczak 2017], polszczyznę Polaków mieszkających poza granicami kraju oraz polszczyznę Polonii należy uznać za nośnik tożsamości narodowej, a w kolejnych pokoleniach tożsamości etnicznej. Na etniczność składają się trzy elementy. Pierwszym $z$ nich jest pojęcie „ojcostwa”, które należy rozumieć jako postrzeganie ciagłości międzypokoleniowej. Za drugi element uznaje się dziedzictwo, zarówno językowe, jak i kulturowe. Ostatnia składowa pochodzenia etnicznego jest fenomenologia samopostrzegania swojej etniczności [Fishmann 1999]. Trzeba podkreślić, że przodkowie, język ojczysty oraz pierwotny model kulturowy to składniki niewybieralne, przekazywane $z$ pokolenia na pokolenie podczas procesu rodzicielskiej socjalizacji pierwotnej [Liebkind 1999; Padilla 1999; Riley 2007], natomiast chęć aktywnej przynależności do grupy etnicznej ma charakter deklaratywny i jest wynikiem autonomicznego wyboru jednostki [Günthner 2017].

Obecnie w naukach społecznych język jest uznawany za główny marker przynależności do określonej grypy etnicznej lub narodowej. Jednak zawsze należy stosować indywidualne podejście, kiedy rozważa się stopień wpływu języka na identyfikację danej osoby $z$ konkretna grupa etniczną lub na postrzeganie jej tożsamości przez innych. Utrata języka nie oznacza automatycznie utraty tożsamości etnicznej, ponieważ identyfikacja grupy mniejszości obejmuje wiele różnych wyznaczników tożsamości, wśród których język jest jednym $z$ najważniejszych, ale nie jedynym [Tabouret-Keller 1998; Fishman 1998; Schmidt 2008]. Zachowanie języka niekoniecznie jest wskaźnikiem etniczności, a administracyjna przynależność nie zawsze odzwierciedla przynależność socjolingwistyczną. 
Wśród użytkowników polszczyzny w kraju język pełni trzy podstawowe funkcje: identyfikacyjna, integracyjna oraz dyferencjacyjną. Pierwsza $z$ nich polega na postrzeganiu siebie jako członka narodu, który, oprócz posługiwania się wspólną mowa, ma wspólną kulturę oraz bliskość psychiczną. Druga funkcja opiera się na jednoczeniu społeczności użytkowników danego kodu językowego. Funkcja dyferencjacyjna pozwala na odróżnienie danej wspólnoty od innej [Mielczarek, Walczak 2017]. Stanisław Dubisz przypisuje polszczyźnie ogólnokrajowej cztery funkcje: jednocząca, separująca, prestiżową oraz normatywną [Dubisz 1997a; Dubisz, Sękowska 1990, 219].

Podobne funkcje pełni polszczyzna wśród Polonii oraz wśród Polaków ${ }^{2}$ mieszkających poza granicami kraju. Dzięki językowi, który jest ich naturalnym kodem komunikacyjnym wśród reprezentantów pokolenia emigracyjnego i pierwszego pokolenia polonijnego, jego użytkownicy dokonuja samoidentyfikacji emocjonalnej jako członków polskiej społeczności. Przedstawiciele diaspory, zamieszkujacy dany obszar geograficzny, nawiązuja kontakty i integruja się ze sobą dzięki znajomości języka polskiego. Widać to przede wszystkim w enklawach polonijnych w krajach mniej zróżnicowanych narodowościowo. Ich komunikacja w języku polskim nie jest wyłącznie aktem mowy. Jest także wyrazem przynależności etnicznej [Rappaport 1990; Masiewicz 1990, 200; Belokoneva-Shiukashvili 2017, 44].

Polszczyzna dla polskich diaspor pełni dodatkowo funkcję kulturotwórczą, która ściśle jest powiązana $z$ tożsamością kulturową [Miodunka 1990b, 122-125; Dubisz 1997b, 37; Błaszczuk 2017]. Dzięki językowi członkowie polonijnej społeczności moga aktywnie uczestniczyć nie tylko w podtrzymywaniu i poznawaniu kultury kraju przodków, ale także w kulturze etnicznej. ${ }^{3}$ Dlatego mówiąc o roli etnolektu, należy przypisać mu także funkcję poznawczą oraz funkcję identyfikacji etnicznej [Dubisz 1997a].

Funkcję dyferencjacyjna języka polskiego poza granicami kraju najlepiej widać w krajach osiedlenia się emigrantów, w których zamieszkuje wiele narodowości, np. Stany Zjednoczone, Kanada, Niemcy, Francja, Wielka Brytania czy Szwecja. Ich mieszkańcy, słysząc język polski, identyfikuja osoby mówiące nim z Polska/Polakami [Brzozowska-Krajka 2017, 122-124; Günthner 2017]. Funkcję tę można porównać do funk-

${ }^{2}$ W taki sam sposób można patrzeć na każdy kod językowy, który na emigracji staje się etnolektem identyfikującym użytkowników $z$ krajem pochodzenia [por. NDiaye 2016, 17].

3 Przez kulturę etniczna rozumiem kulturę, której twórcami sa reprezentanci danej mniejszości narodowej, w tym wypadku osoby polskiego pochodzenia oraz Polonia. W Stanach Zjednoczonych za taką osobę można uznać np. Agatę Stopę, autorkę powieści historycznej Świętosława - królowa Wikingów [2016], dyrektor Polskiej Szkoły im. Fryderyka Chopina - Allamuchy, New Jersey. 
cji ekskluzywnej [Rappaport 1990] oraz separującej, zaproponowanej przez Stanisława Dubisza [Dubisz 1997a].

Przyglądając się polskiej mniejszości narodowej w strefach, które dla językoznawców mogą wydawać się „egzotyczne” $z$ racji nie tylko odległości geograficznej, ale przede wszystkim genealogii - chodzi tu o czwarte lub nawet piate pokolenie polonijne, należy mówić jeszcze o jednej funkcji - symbolicznej. Przedstawiciele Polonii uczą się języka, ale przeważnie opanowuja go w stopniu komunikatywnym i nie sa w stanie posługiwać się nim płynnie w kontaktach $z$ rodzimymi użytkownikami, którzy odwiedzaja te tereny. Polszczyzna jest dla nich namiastka kraju i kultury przodków, która przez lata urosła do rangi symbolu. Stan ten bardzo często jest skutkiem prób wykorzenienia języka rodzimego wraz $z$ jego kultura [Smolicz 1990; Karaś 1997a; Karaś 1997b; Sękowska 2010, 86-87; Sadowska 2017, 53; Wichniewicz 2017]. Ma to przede wszystkim podłoże polityczne. ${ }^{4}$

Pracujac z uczniami w polonijnych szkołach sobotnich w Stanach Zjednoczonych, którzy przeważnie są reprezentantami pierwszego lub drugiego pokolenia polonijnego, można mówić także o rytualnej funkcji języka polskiego, o której wspominają w wypadku emigrantów Gilbert Rappaport oraz Elżbieta Sękowska [Rappaport 1990, 161; Sękowska $2010,86]$. Szczególnie jest to widoczne wśród dzieci przystępujących do pierwszej komunii świętej w polskich parafiach oraz wśród dziewcząt i chłopców przyjmujących sakrament bierzmowania. Opanowanie poszczególnych modlitw $z$ wyznaczonego kanonu jest trudnym wyzwaniem, ponieważ ich kompetencja językowa nie pozwala na pełne zrozumienie tekstu. Poszczególnych tekstów uczą się na pamięć i recytuja je podczas mszy lub innych nabożeństw bez zrozumienia. Zaistniała sytuacja wynika także $z$ tego, że szereg modlitw zawiera leksykę i składnię archaiczna - staropolska, która stwarza problemy także rodzimym użytkownikom języka polskiego.

Podobna sytuacja ma miejsce na Ukrainie, gdzie kościół katolicki jest miejscem pielęgnowania polszczyzny, mimo że pod koniec lat 90 . XX wieku nastapiła jego depolonizacja. Polszczyzna była stopniowo zastępowana językiem ukraińskim oraz rosyjskim, ale nadal pozostała językiem liturgii w miejscach zamieszkiwanych przez ludność mówiąca w domach po polsku. Pavlo Levchuk w swoim opracowaniu wspomina o parafiach, w których odprawiane są dwujęzyczne nabożeństwa. Części stałe, akty wiary oraz modlitwa eucharystyczna wybrzmiewaja po polsku, natomiast czytania, ewangelia oraz kazania w języku ukraińskim lub rosyjskim [Levchuk 2020, 43]. Nie należy postrzegać tego jako coś złego, ale raczej jako naturalny proces $\mathrm{w}$ środowiskach wielokulturowych oraz wieloję-

${ }^{4}$ We współczesnej Europie ze zjawiskiem tym spotykamy się przede wszystkim na Bałkanach, gdzie w wyniku zmian geopolitycznych dochodzi do prób wykorzenienia języków etnicznych. 
zycznych i w krajach, które niedawno odzyskały swoja niepodległość, a do takich należy Ukraina.

Funkcje języka polskiego wśród polskiej emigracji stale ulegają zmianom od momentu zamieszkania w nowym kraju. Polszczyzna zaczyna funkcjonować obok nowego języka. Płynnie wchodzi z nim w kontakt, kiedy emigrant zaczyna używać odmiennego kodu komunikacyjnego (kodów komunikacyjnych - w wypadku kraju bilingwalnego, np. Belgia czy Szwajcaria). Stopniowo polski przestaje być głównym językiem komunikacji, stale konkurując $z$ językiem kraju osiedlenia, ustępuje mu już nawet w codziennym życiu pokolenia emigracyjnego, żeby w trzecim lub czwartym pokoleniu ulec jego ograniczonej znajomości [Miodunka 1990b, 47].

Status języka polskiego poza Polska, tak jak jego funkcje, może być różnoraki. Najczęściej w badaniach lingwistycznych o polszczyźnie polonijnej mówi się jako o języku drugim, a ostatnio coraz częściej jako odziedziczonym. W opracowaniach $z$ zakresu dydaktyki języka znajdziemy także sformułowania język obcy oraz nierodzimy. Te dwa ostatnie pojęcia można także odnieść do reprezentantów polskiej grupy etnicznej, którzy nie nabywaja polszczyzny w warunkach domowych, a uczą się jej w sposób sformalizowany, będąc reprezentantami III lub IV pokolenia polonijnego.

Polszczyzna, która posługują się jej użytkownicy w USA oraz na Ukrainie ma odmienny status niż polszczyzna w kraju, ponieważ nie jest jedynym i podstawowym kodem komunikacji. Dlatego też jej społeczny zakres komunikatywny jest ograniczony. Biorąc pod uwagę, że posługuja się nią osoby polskiego pochodzenia albo osoby uczące się w tym języku - uczniowie szkół z oddziałami dwujęzycznymi, można przypisać jej status języka etnicznego o zasięgu lokalnym. Można usłyszeć go wyłącznie tam, gdzie mieszkaja Polacy lub osoby związane $z$ Polską. W stosunku do języka amerykańskiego w Stanach Zjednoczonych, a w stosunku do języka ukraińskiego oraz rosyjskiego na Ukrainie, język polski pełni funkcję dialektu, który jednoczy jego użytkowników.

Ze względu na kryterium normatywno-kodyfikacyjne status polszczyzny polonocentrycznych zbiorowości poza granicami kraju jest skomplikowany. Jego związek $z$ diasporycznościa, uzualnościa oraz mieszany charakter uniemożliwia wykorzystanie do jego oceny i kodyfikacji tych samych narzędzi, które są używane w ocenie języka polskiego w kraju [Dubisz 1997, 22].

Użytkownicy języka polskiego w Stanach Zjednoczonych i na Ukrainie maja świadomość swoich trudności językowych, które najlepiej widać w kontaktach $z$ nowo przybyłymi emigrantami w USA oraz $z$ polskimi turystami na Ukrainie, którzy posługują się standardową polszczyzną. Oczywiście każda $z$ tych grup ma inne problemy natury językowej, które wynikają $z$ języka / języków kraju zamieszkania: język polski $\leftrightarrow$ język angielski, język polski $\leftrightarrow$ język ukraiński, język polski $\leftrightarrow$ język rosyjski. 
Wynikają one $z$ różnic genetycznych, fonologiczno-fonetycznych, morfologicznych, syntaktycznych w stosunku do polszczyzny.

Język polski poza granicami kraju ma głównie status języka familijnego, ponieważ jego użytkownicy posługuja się nim przede wszystkim w domach, podczas spotkań towarzyskich, w polskich miejscach kulturalnych, w szkołach dwujęzycznych lub w szkołach sobotnich. W Stanach Zjednoczonych, Niemczech, Irlandii czy w Wielkiej Brytanii jest kodem komunikacyjnym $\mathrm{w}$ miejscach publicznych ulokowanych $\mathrm{w}$ polskich osadach, np. sklepach, zakładach samochodowych, salonach fryzjerskich czy bankach [Jędryka 2012; Karaś 2015].

Ważne jest określenie statusu polszczyzny poza krajem dla najmłodszych jej użytkowników. Oczywiście w wielu aspektach jest on taki sam jak w wypadku osób dorosłych. Jednak od początku XXI wieku zaczęto dokładniej przyglądać się językowi polskiemu w rodzinach polonijnych i głośno mówić o tym, że ma on cechy języka odziedziczonego (ang. heritage language), którego pojęcie na grunt polski zostało wprowadzone przez E. Lipińską oraz A. Seretny [Lipińska, Seretny 2012a; 2012b]. ${ }^{5}$ Według początkowych założeń teoretycznych język odziedziczony (JOD) jest językiem ojczystym funkcjonalnie drugim, przez co należy rozumieć, że pierwszym funkcjonalnym kodem komunikacyjnym w codziennych kontaktach jest język kraju urodzenia i zamieszkania potomków pokolenia emigrantów. Tak jak w wypadku języka familijnego, JOD jest językiem używanym w środowisku domowym, którego najstarsi członkowie nie posługują się językiem kraju zamieszkania, np. angielskim, lub znaja go w stopniu ograniczonym. ${ }^{6}$

5 Mimo że badaczki zaszczepiły pojęcie języka odziedziczonego, to w pracach z zakresu dydaktyki języka polskiego poza krajem, szczególnie w polonijnych diasporach, rozgraniczają użytkowników języka polskiego jako odziedziczonego oraz użytkowników języka polskiego jako domowego [Lipińska, Seretny 2016a]. Według nich odmiana domowa to przede wszystkim forma mówiona polszczyzny w środowisku polonijnym, która odbiega od standardowej, ogólnej odmiany języka polskiego. Natomiast język odziedziczony to tak naprawdę język domowy, którego w sposób formalny uczą się dodatkowo dzieci w polonijnych szkołach sobotnich / dokształcających, przez co należy rozumieć, że rozwijaja wszystkie sprawności językowe: mówienie, rozumienie ze słuchu, czytanie oraz pisanie w obszarze języka standardowego.

6 Należy jednak zaznaczyć, że pod pojęciem języka odziedziczonego kryją się nie tylko kody językowe imigrantów, ale także języki natywne na określonym obszarze zagrożone wymarciem oraz języki osadników, które $z$ biegiem czasu uzyskały status języka mniejszości [Fishman 2001]. E. Lipińska i A. Seretny słusznie poszerzyły to pojęcie o języki natywne na danym terytorium, których użytkownicy $z$ przyczyn od nich niezależnych, takich jak przesunięcie granic w wyniku zmian politycznych, zostaja pozbawieni realnego kontaktu ze swoim językiem [Lipińska, Seretny 2016b]. W amerykańskich opracowaniach prawdopodobnie zabrakło tej kategorii, ponieważ $z$ takim zjawiskiem nie spotkali się 
Użytkownikami języka odziedziczonego, zgodnie $z$ założeniami teoretycznymi, sa osoby należące do pierwszego pokolenia imigrantów oraz pokoleń kolejnych, których przedstawiciele urodzili się w nowym kraju osiedlenia dziadków i od wczesnego dzieciństwa dorastają w dwujęzycznym środowisku. Należy podkreślić, że językiem dominującym w pierwszym etapie rozwoju językowego jest przeważnie język, którym posługują się rodzice/opiekunowie. Jest to kod językowy, który dziecko poznaje jako pierwszy w formie słuchowo-mówionej i zazwyczaj w takiej pozostaje, jeśli dziecko nie uczy się ani czytać, ani pisać w tym języku lub opanowuje te sprawności w małym stopniu.

Osoby posługujace się JOD nie uczą się go w dzieciństwie w sposób formalny, tak jak odbywa się to w wypadku języka obcego. Proces opanowywania systemu jest naturalny, ponieważ nabywaja JOD od najbliższych, tak jak ma to miejsce podczas akwizycji języka ojczystego. Tak jak rodzimi użytkownicy, dysponuja umiejętnościami w zakresie morfosyntaktyki, słowotwórstwa oraz mają bogatszy zasób słów niż np. cudzoziemcy uczący się języka polskiego jako obcego. Jednak ich słownik czynny oraz bierny ogranicza się przede wszystkim do słownictwa podstawowego i to do tego, które dotyczy sfery prywatnej [Lipińska, Seretny 2016a; 2016b]. W ich wypowiedziach pojawiają się liczne usterki językowe w obszarze morfologiczno-składniowym oraz fonologicznym, których charakter ma inne podłoże lingwistyczne niż tych popełnianych przez użytkowników polszczyzny, dla których język polski jest językiem obcym. Błędy w obszarze systemu powstaja przede wszystkim na skutek interferencji języka funkcjonalnie pierwszego. ${ }^{7}$

$Z$ psychologicznego punktu widzenia użytkowników JOD od innych odróżnia także emocjonalny związek $z$ językiem jako nośnikiem tożsamości etnicznej, która przejawia się w pielęgnowaniu tradycji oraz obyczajowości kraju przodków. Tego istotnego elementu brakuje osobom znającym polszczyznę o wiele lepiej niż przedstawiciele polskich grup etnicznych, dla których język polski jest językiem edukacji, ale nadal jest językiem obcym, w którym mimo wysokiej kompetencji trudno jest także wyrażać uczucia i emocje. Mam tu na myśli dzieci z doświadczeniem migracyjnym uczace się w szkołach w Polsce.

Na przykładzie Polonii amerykańskiej oraz osób polskojęzycznych na Ukrainie widać także, że użytkownicy polszczyzny chętnie i aktywnie biora udział w życiu kulturowym polskich diaspor. Rodzice dzieci, dla

lingwiści budujący teorię języków odziedziczonych, które odnosiły się do krajów Ameryki Północnej.

7 Ałła Krawczuk, za E. Dzięgiel, analizując szczegółowo sytuację językowa dzieci i młodzieży na Ukrainie, proponuje używanie terminu język przodków $\mathrm{w}$ wypadku polszczyzny na tym obszarze. Jest to pojęcie o szerszym zakresie i lepiej odzwierciedla status języka polskiego, ponieważ obejmuje ono wszystkich reprezentantów tej grupy wiekowej, niezależnie od ich poziomu biegłości językowej, zanim rozpoczęli oni formalną naukę języka [Krawczuk 2019]. 
których język polski jest językiem odziedziczonym, dbają o to, żeby miały one możliwość uczenia się/rozwijania go w sposób formalny w sobotnich szkołach dokształcających działających przy Centrali Polskich Szkół Dokształcajaccych w Ameryce $z$ siedziba w Nowym Jorku oraz przy Zrzeszeniu Nauczycieli Polskich w Ameryce $z$ siedziba w Chicago. Na terenie Ukrainy należy wymienić na przykład takie organizacje jak: Centrum Kultury Polskiej i Dialogu Europejskiego w Iwano-Frankiwsku, Żytomierskie Polskie Centrum Edukacji i Nauki w Żytomierzu czy Związek Nauczycieli Polskich na Ukrainie w Drohobyczu. Oświatowe organizacje polonijne starają się o stały kontakt dzieci $z$ rodzimymi użytkownikami języka polskiego $\mathrm{w}$ kraju, organizując letni wypoczynek razem $z$ rówieśnikami z Polski.

W XXI wieku zyskała na popularności edukacja dwujęzyczna, która dotyczy także języka polskiego poza granicami Polski. Coraz częściej spotykamy klasy $z$ wykładowym językiem polskim, będacym drugim kodem, w którym odbywa się nauka - czasami sa to tylko wybrane przedmioty. Jest to uzależnione od systemu kształcenia przyjętego w danym państwie oraz w danej placówce edukacyjnej. Do wyboru jest kilka możliwości rozwiązań pedagogicznych oraz systemowych, np. dual language bilingual education, heritage language bilingual education, immersion bilingual education, bilingual education in majority languages [Baker, Wright 2017]. Przy takim założeniu polszczyzna ma status i funkcję języka edukacji szkolnej (JES), który staje się narzędziem zdobywania wiedzy o świecie. Wówczas sytuacja dzieci i młodzieży uczącej się w takim systemie zbliżona jest do językowych warunków edukacyjnych uczniów $z$ doświadczeniem migracji (UDM) w Polsce [Jędryka, 2014; Jędryka 2015; Szybura 2016a; Pamuła-Behrens 2018; Pamuła-Behrens, Szymańska 2018a; Pamuła-Behrens, Szymańska 2018b; Seretny 2018].

Konieczne jest zaznaczenie w tym miejscu, że uczniami oddziałów $z$ polskim językiem wykładowym nie zawsze są dzieci, które maja polskie pochodzenie. Moje badania w Stanach Zjednoczonych oraz na Ukrainie pokazuja, że coraz częściej w szkolnych ławkach zasiadają najmłodsi rozpoczynający naukę polszczyzny od podstaw w sytuacji, w której jest ona początkowo językiem obcym przechodzacym w język edukacji. Oczywiście proces nauki, w tym wypadku nabywania języka, jest zupełnie inny niż podczas standardowych zajęć $z$ języka obcego, o czym będzie mowa w dalszej części niniejszego opracowania. Na podstawie danych zebranych w latach 2018-2021 w Stanach Zjednoczonych (Nowy Jork, Chicago) oraz na Ukrainie (Iwano-Frankiwsk) w szkołach, które realizowały nauczanie dwujęzyczne w języku polskim w obu państwach, około $17 \%$ uczniów nie miało żadnych powiązań rodzinnych $z$ Polską.

Zaistniała sytuacja edukacyjna nie powinna dziwić, ponieważ na świecie jest powszechnym zjawiskiem to, że dzieci coraz częściej uczą się $\mathrm{w}$ językach, które nie sa ich kodami prymarnymi, pełniącymi jednocześnie funkcje języka administracyjnego kraju zamieszkania. Tendencja ta 
dotyczy głównie języka angielskiego, niemieckiego oraz francuskiego, ale obserwuje się ją także w krajach sąsiadujących $z$ państwem, które może być potencjalnym miejscem emigracji rodziców, np.: Ukraina $\rightarrow$ Polska, Polska $\rightarrow$ Niemcy, Polska $\rightarrow$ Wielka Brytania. Rodzice, biorac pod uwage relokację lub podjęcie $\mathrm{w}$ przyszłości studiów przez ich dzieci w obcym kraju, decyduja się właśnie na edukację dwujęzyczną lub edukację w języku obcym dla dziecka.

\section{NAUKA JĘZYKA POLSKIEGO NAJMEODSZYCH}

Przyglądając się nauczaniu polszczyzny jako języka etnicznego, ale nie tylko, poza granicami w polskich diasporach, należy stwierdzić, że jest ono bardzo dobrze zorganizowane na całym świecie oraz wspomagane przez polskie władze, które powołały do życia Ośrodek Rozwoju Polskiej Edukacji za Granica (ORPEG) - instytucję zajmująca się od 1973 roku wspieraniem i promowaniem nauki języka polskiego wśród młodych Polaków przebywajacych za granica. Trzeba jednak podkreślić, że dużą rolę w krzewieniu polszczyzny i polskiej kultury odgrywaja instytucje oświatowe działające w poszczególnych państwach, pozostające poza nadzorem ORPEG-u. Dzięki ich ścisłej współpracy $z$ polskimi organizacjami pozarzadowymi oraz samodzielnym staraniom szkolnictwo polonijne funkcjonuje na bardzo wysokim poziomie. Polska należy do grona niewielu krajów na świecie, których język jest tak mocno podtrzymywany poza ich granicami administracyjnymi.

Nauka języka polskiego przez osoby polskiego pochodzenia, mieszkające poza krajem, przybiera różne formy, nieformalne oraz formalne. Wśród pierwszych dominuje nabywanie polszczyzny w środowisku domowym i jest naturalnym procesem akwizycji, jeżeli przynajmniej jedno $z$ rodziców posługuje się nią na poziomie przeciętnego Polaka. Ważnym elementem rozwoju językowego jest kontakt $z$ innymi użytkownikami języka, np.: babcią, dziadkiem czy dalszą rodzina, którzy wpływają na kształtowanie się słuchu fonematycznego, prozodii, systemu gramatycznego, składni oraz zasobu leksykalnego w obrębie polszczyzny. Oczywiście dziecko może otrzymywać dodatkowe bodźce językowe $z$ wykorzystaniem najnowszej technologii - radio, telewizja, Internet, jednak najważniejsze jest wchodzenie $\mathrm{w}$ interakcje językowe $z$ innymi użytkownikami języka, podczas których dziecko odgrywa rolę nie tylko odbiorcy, ale także nadawcy komunikatów. ${ }^{8}$

8 Mówiąc o nieformalnej nauce języka, należy wspomnieć także o sytuacji, która nie zdarza się często, że dzieci uczą się go od rówieśników, z którymi spędzają bardzo dużo czasu. Dotyczy to głównie najmłodszych, którzy nie sa związani z polszczyzna genetycznie, to znaczy nie maja polskiego pochodzenia, i jest ona dla nich językiem obcym. 
Przyglądając się formalnym rozwiązaniom nauki języka polskiego poza Polska, można zauważyć, że przypominają one te stosowane systemowo w kraju - przedszkole, szkoła podstawowa, liceum. Jeżeli jest taka możliwość, to dzieci powyżej trzeciego roku życia sa zapisywane do polskojęzycznych oddziałów przedszkolnych prowadzonych od poniedziałku do piątku w okolicach zamieszkania rodziny. Częściej jednak jedynym rozwiązaniem dla rodziców sa zajęcia dla przedszkolaków, które sa organizowane przy polskich szkołach sobotnich. Właśnie ta forma kształcenia językowego najmłodszych jest powszechna wśród polskich rodzin, ponieważ stanowi przygotowanie do dalszej nauki języka oraz adaptacji kultury polskiej w sobotniej szkole podstawowej, a następnie w klasach licealnych, jeżeli takie są. Trzeba podkreślić, że zajęcia dla kilkulatków mają walory integrujace ich ze środowiskiem polskojęzycznym. Już od wczesnych lat poznaja oni miejsca i ludzi zwiazanych $z$ polskościa oraz uczestnicza w wydarzeniach nie tylko kulturalnych, ale także religijnych.

Oczywiście udział w zajęciach przedszkolnych nie jest konieczny, aby rozpoczać naukę języka polskiego dopiero w pierwszej klasie szkoły sobotniej. Znajomość podstaw polszczyzny, nabytych droga formalna czy nieformalna, nie decyduje o tym, czy dziecko zostanie przyjęte do placówki czy nie. Struktura szkoły podstawowej jest dostosowana do realiów oświatowych państwa, w którym mieszkają osoby polskiego pochodzenia. Tak więc organizacja procesu dydaktycznego od strony administracyjnej różni się w każdym kraju, co dobrze widać na przykładzie Stanów Zjednoczonych oraz Ukrainy.

W szkołach polonijnych dzieci uczą się języka etnicznego, który jest przede wszystkim językiem odziedziczonym. To wymaga stosowania innych założeń metodycznych nauczania polszczyzny, specjalnie opracowanych programów oraz materiałów dydaktycznych, $z$ wykorzystaniem wiedzy $z$ zakresu interferencji językowych oraz kulturowych. ${ }^{9} \mathrm{~W}$ szkołach sobotnich język polski jest także językiem edukacji, ponieważ to w nim dzieci zdobywaja oraz poszerzaja swoja wiedzę o Polsce, jej historii oraz geografii. Jednak nauka nie tylko języka, ale także w języku odbywa się przede wszystkim w szkołach dwujęzycznych, o których wspomniałam w poprzedniej części niniejszego artykułu, dotyczącej statusu i funkcji języka.

W tym miejscu trzeba wspomnieć, że dzieci polskiego pochodzenia, ale nie tylko one, jeżeli nie mają możliwości uczęszczać do przedszkola

$9 \mathrm{Na}$ potrzeby szkolnictwa polonijnego sa przygotowywane specjalne materiały dydaktyczne, które uwzględniają nie tylko metodykę nauczania języka polskiego jako obcego, ale także języka odziedziczonego. Na Ukrainie dla dzieci starszych wykorzystywana jest seria Raz, dwa, trzy i po polsku mówisz Ty (red. P. Kajak), natomiast w Stanach Zjednoczonych od 2020 roku na Wschodnim Wybrzeżu uczniowie klas pierwszych rozpoczęli pracę $z$ trzyletnim podręcznikiem Polskie niezapominajki (red. B. Jędryka). 
oraz szkoły sobotniej, moga uczestniczyć w zajęciach o charakterze kursu językowego, na których polszczyzna jest nauczana jako język obcy. Niestety dla uczniów w wieku wczesnoszkolnym trudno jest znaleźć bogata ofertę edukacyjną adresowaną właśnie do tej grupy wiekowej, niezależnie od miejsca zamieszkania na świecie. Prawdopodobnie jest to zwiazane $z$ „raczkująca” jeszcze glottodydaktyka polonistyczną dla najmłodszych oraz niewielka liczba pozycji dydaktycznych przygotowanych $z$ myśla o najmłodszych.

W Stanach Zjednoczonych nauczanie języka polskiego oraz w języku polskim odbywa się w szkołach dokształcajacych, które sa placówkami samodzielnymi albo afiliowanymi. Pierwszy typ to szkoła, która nie jest zrzeszona $\mathrm{w}$ żadnej $\mathrm{z}$ istniejacych $\mathrm{w}$ USA central edukacyjnych, natomiast drugi to każda instytucja edukacyjna zwiazana w sposób bezpośredni $z$ jedna $z$ czterech kuratoryjnych organizacji patronackich. ${ }^{10}$ Dodatkowo mówi się także o szkołach sobotnich autonomicznych, nieuzależnionych od instytucji lub organizacji zwierzchnich, oraz o szkołach nieautonomicznych - placówkach nieposiadajacych pełnej samodzielności [Jędryka, 2017].

Dzieci i młodzież uczą się języka przodków głównie w systemie weekendowym. Zajęcia dydaktyczne odbywają się głównie w soboty, ale niektóre szkoły ze względu na dużą liczbę uczniów zmuszone są organizować zajęcia także w piątki, ponieważ warunki lokalowe nie pozwalaja im na pracę ze wszystkimi uczniami w tym samym czasie. Na naukę w ciagu roku przeznaczonych jest trzydzieści trzygodzinnych spotkań, podczas których uczniowie doskonalą swoje sprawności językowe (mówienie, słuchanie, czytanie oraz pisanie), ucza się historii oraz geografii Polski.

W szkołach dokształcajacych istnieje tradycyjny model kształcenia przedszkole, szkoła podstawowa oraz liceum. Oczywiście nie we wszystkich placówkach sa oddziały klas licealnych. Ich obecność w strukturze jest uzależniona od zapotrzebowania środowiska lokalnego, ponieważ większość uczniów szkół sobotnich kończy swoją edukację na poziome szkoły podstawowej i tylko niezbyt duży odsetek młodzieży chce kontynuować naukę. Dydaktyka odbywa się w systemie klasowym, a poszczególne placówki edukacyjne sa różnej wielkości. Sa wśród nich i takie, które maja po kilku lub kilkunastu uczniów, ale sa też szkoły mające ich ponad 500 lub 800. Dodatkowo szkoły polonijne oferuja swoim uczniom, oprócz nauki języka, także zajęcia taneczne, teatralne oraz muzyczne.

$Z$ roku na rok coraz większa popularnością cieszy się w Stanach Zjednoczonych dwujęzyczny program edukacyjny dostępny w wybranych

10 Na terenie Stanów Zjednoczonych nadzór merytoryczny oraz organizacyjny nad szkolnictwem polonijnym pełnią: Centrale Polskich Szkół Dokształcajacych w Ameryce (Nowy Jork), Zrzeszenie Nauczycieli Polskich w Ameryce (Chicago), Forum Nauczycieli Polskich Zachodniego Wybrzeża (Los Angeles), Zwiazek Nauczycieli Polskich w Michigan (Detroit). 
szkołach amerykańskich - Polish-English Dual Language Program (DLP). Założenie edukacyjne tej formy kształcenia dzieci polonijnych, i nie tylko, polega na tym, że treści edukacyjne sa przyswajane przez uczniów $\mathrm{w}$ dwóch językach - polskim oraz angielskim. Uczniami w klasach realizujacych program sa dzieci, dla których polszczyzna jest językiem odziedziczonym, ale także osoby niemające powiązań $z$ Polską i jej językiem. Ta forma nauczania dostępna jest w Chicago oraz w Nowym Jorku. Bardzo często zdarza się, że dzieci polonijne uczęszczające do szkół z programem DLP dodatkowo biora udział w zajęciach szkół sobotnich. Oczywiście rodzice zdaja sobie sprawę, że może być to obciązające dla dziecka, jednak decyduja się na ten krok ze względu na nabywanie przez nie wiedzy w zakresie historii i geografii Polski. Treści tych brakuje w szkołach amerykańskich $z$ DLP, a jeżeli sa wprowadzane fakultatywnie przez nauczycieli, to $\mathrm{w}$ zminimalizowanym zakresie. Nie dotyczy to tylko języka polskiego oraz wiedzy o naszym kraju. Tak samo wygląda edukacja w DLP w zakresie języka francuskiego, hiszpańskiego czy rosyjskiego.

Obecnie na terenie Nowego Jorku nauczanie dwujęzyczne $z$ językiem polskim jest realizowane w trzech placówkach edukacyjnych P.S. 034 Oliver H. Perry (Brooklyn), P.S. 071 Forest (Queens) oraz Daniel Street Elementary School w Lindenhurst (Long Island). W najbardziej znanej enklawie polskiej w USA Chicago $z$ DLP korzystaja uczniowie w szkole podstawowej Clearmont Elementary School w Elk Grove Village.

Język polski, nawet jako język etniczny, zyskał znaczna popularność na Ukrainie po odzyskaniu przez nią niepodległości w 1991 roku. Najmłodsi użytkownicy polszczyzny mogą uczyć się jej jako języka mniejszości narodowej, języka ojczystego oraz języka obcego. Status edukacyjny języka jest związany przede wszystkim $z$ jego forma nauczania oraz uwarunkowaniami legislacyjnymi. Podobnie jak w Stanach Zjednoczonych, ukraiński system edukacji pozwala na uczenie się języków mniejszości narodowych przez osoby ich nieznajace, a mieszkajace w miejscowościach, w których używa się tych języków. W takich klasach uczą się nie tylko Polacy, ale także osoby niepolskiego pochodzenia. W samym Lwowie w 2016 roku stanowiły one 15\% uczniów [Szumlańska 2013; Krawczuk, Kowalewski 2017; Levchuk 2020, 41].

Biorąc pod uwagę status, rangę oraz typ szkoły, w której edukacja odbywa się w języku polskim lub naucza się go jako języka obcego, wyróżniamy kila grup placówek edukacyjnych. W ramach kształcenia publicznego polszczyzna pojawia się $\mathrm{w}$ szkołach $z$ polskim językiem wykładowym (szkoły poczatkowe - klasy I-IV, szkoły podstawowe klasy I-IX, szkoły średnie - klasy I-IX), w szkołach średnich $z$ pionem polskim sa to polskie klasy w szkołach wielojęzycznych oraz w szkołach $z$ pogłębiona nauka języka polskiego, gdzie wprowadzono naukę $z$ myśla o mniejszości narodowej. Dydaktyka w szkołach publicznych prowadzona jest według rozwiazań opracowanych oraz zatwierdzonych przez odpowiednie organy na Ukrainie. W latach 2000-2010 powstały pro- 
gramy do nauki polskiego w szkołach $z$ polskim językiem nauczania oraz program do nauki języka polskiego jako języka obcego w szkole ukraińskojęzycznej. W roku 2012 przygotowano programy do nauki języka polskiego jako języka mniejszości narodowej w szkołach $z$ ukraińskim językiem nauczania. Języka polskiego dzieci uczą się także w ukraińskich szkołach, w których ma on status języka obcego i jest przedmiotem albo obowiazkowym, albo fakultatywnym. Nauka odbywa się według programów zatwierdzonych przez władze ukraińskie.

Obok szkolnictwa publicznego funkcjonuje szkolnictwo społeczne, które zajmuje się nauczaniem polszczyzny. Sa to dwa typy szkół sobotnich - zarejestrowane i niezarejestrowane, działajace przy polskich organizacjach oraz parafiach rzymskokatolickich. W pierwszych $z$ nich język polski ma status języka mniejszości narodowej i jest nauczany według wytycznych przygotowanych przez ukraińskie Ministerstwo Oświaty i Nauki, które zatwierdza także materiały dydaktyczne wykorzystywane do dydaktyki - taka procedurę musiała przejść najnowsza seria do nauki języka polskiego Raz, dwa, trzy i po polsku mówisz Ty. Drugi typ szkół naucza języka polskiego jako ojczystego, a treści dydaktyczne nie sa przedstawiane do akceptacji ukraińskim władzom. Nauczyciele przygotowuja autorskie programy, do których realizacji wykorzystuja podręczniki ze szkół w Polsce lub materiały dydaktyczne adresowane do cudzoziemców uczących się języka polskiego jako obcego na całym świecie.

Z zajęć językowych można także korzystać na kursach, do których zalicza się także indywidualne lekcje. Polszczyzna nauczana jest tam przede wszystkim jako język obcy i dlatego też nauczyciele korzystają $z$ programów oraz podręczników opracowanych w Polsce dla tej grupy odbiorców. Dużym powodzeniem wśród uczniów i nauczycieli cieszą się materiały z serii Hurra! Po polsku oraz Polski krok po kroku. Zajęcia organizowane sa przy polskich towarzystwach, parafiach rzymskokatolickich oraz szkołach ukraińskich. Tak jak w Stanach Zjednoczonych, polonijne centra kultury oraz organizacje takie jak np. Związek Polaków na Ukrainie, Federacja Organizacji Polskich na Ukrainie oprócz lekcji polskiego oferuja także uczestnictwo w zajęciach tanecznych oraz wokalnych.

\section{SLOWNICTWO W DYDAKTYCE JĘZYKA POLSKIEGO DZIECI}

Nauczanie słownictwa w procesie dydaktycznym na każdym poziomie zaawansowania oraz w każdej grupie wiekowej jest istotnym działaniem dydaktycznym, ponieważ to właśnie słowa służą do nazywania tego, co nas otacza. Kompetencja leksykalna (KL), także dla rodzimych użytkowników języka, jest jedną $z$ najważniejszych, ponieważ pozwala na pełne uczestniczenie $\mathrm{w}$ życiu społecznym, naukę oraz dzielenie się $z$ innymi własnym światopoglądem. Badacze języka oraz metodycy naucza- 
nia języków rodzimych, drugich i obcych zgodnie uważaja, że jest ona niezbędnym czynnikiem warunkującym przyswajanie języka. Problem pojawia się wówczas, kiedy należy przypisać ją jako składową kompetencji komunikacyjnej czy lingwistycznej. Poddając analizie znajomość słownictwa przez dzieci w wieku wczesnoszkolnym, które uczą się języka polskiego poza granicami Polski, należy patrzeć na kompetencję leksykalna $z$ punktu widzenia dydaktyki języków obcych - jako składowa kompetencji lingwistycznej. ${ }^{11}$ Takie podejście, zarówno dydaktyczne jak i badawcze, wynika $z$ tego, że mali uczniowie, aby poszerzyć swój zasób słów $z$ różnych zakresów tematycznych, muszą uczyć się języka w sposób formalny pod okiem nauczyciela. Nawet ci, którzy pochodzą z polskich rodzin, nie mają możliwości wzbogacenia leksykonu, ponieważ w codziennych sytuacjach komunikacyjnych używana jest ograniczona liczba wyrazów, a znajomość około 2000 jednostek wysokofrekwencyjnych umożliwia dostępność leksykalną około 80\% treści komunikatów w danym języku [Zgółkowa 1992].

Na podstawie badań własnych oraz doniesień dotyczacych badań nad innymi językami, np. chińskim, należy zakładać, że zasób leksykalny uczniów klas wczesnoszkolnych, którzy uczą się języka polskiego w szkołach sobotnich oraz w klasach dwujęzycznych, jest zróżnicowany pod względem ilościowym oraz jakościowym. Dotyczy to wszystkich sfer życia człowieka oraz sytuacji komunikacyjnych, w których znajduja się dzieci w przedziale wiekowym 6-10 lat. Na taką sytuację składa się wiele czynników, zarówno socjolingwistycznych, jak i edukacyjnych, które sa ściśle zwiazane ze statusem oraz funkcja języka polskiego w danym kraju oraz diasporze.

Słownik małych użytkowników polszczyzny jako języka odziedziczonego oraz języka familijnego na pewno jest większy niż słownik dzieci $\mathrm{w}$ tym samym wieku, dla których język polski jest językiem obcym, ponieważ dla tych pierwszych jest to zazwyczaj kod prymarny, który dominuje w sytuacjach życia domowego oraz w kontaktach $z$ najbliższym środowiskiem. Wraz z rozwojem językowym dzieci, stymulowanym rozmowami lub czytaniem książek, zwiększa się ich zasób słów, zarówno w obszarze percepcji, jak i produkcji. Sytuacja ta ulega zmianie, kiedy w ich życiu zaczyna dominować język kraju zamieszkania, co dzieje się $\mathrm{w}$ momencie rozpoczęcia nauki w tzw. zerówce, która ma za zadanie przygotować je do pójścia do szkoły.

U dzieci uczęszczających do szkół sobotnich oraz klas dwujęzycznych, w porównaniu $z$ tymi, które uczą się języka polskiego na zajęciach kursowych lub indywidualnych, obserwuje się odmienny przyrost słownictwa. Zwiazane jest to $z$ tym, że podczas lekcji sobotnich oraz lekcji

11 Podobnie patrzy na kompetencję leksykalną Anna Seretny, badając zasób słownika osób dorosłych uczących się języka polskiego jako obcego [Seretny 2011; Seretny 2015]. 
w szkole uczniowie uczą się w języku polskim. Tak intensywny kontakt $z$ językiem pod okiem nauczyciela, często rodzimego użytkownika języka, odgrywa dużą rolę we wzbogacaniu leksykonu, który obejmuje już nie tylko słownictwo ogólne, ale także specjalistyczne, reprezentowane przez różne dziedziny nauki (np. historia czy geografia).

Badanie kompetencji leksykalnej wśród najmłodszych użytkowników polszczyzny poza krajem jest zagadnieniem, które nieczęsto pojawia się wśród zainteresowań językoznawców, w przeciwieństwie do badań młodzieży i osób dorosłych. Jej opisy sa zazwyczaj składową większych badań lingwistycznych i nie poświęca się jej zbyt dużo miejsca. Pierwsze badania wśród uczniów drugich klas polonijnych szkół dokształcajacych w Stanach Zjednoczonych przeprowadziłam w latach 2005-2010. Wówczas już na etapie projektowania badania, którego głównym celem było poznanie jakości polszczyzny uczniów, podczas pilotażowych obserwacji dzieci okazało się, że to nie błędy gramatyczne i fonetyczne stanowiły ich największy problem. W trakcie lekcji oraz rozmów $z$ rówieśnikami w języku polskim dzieciom brakowało słów, aby wyrażać swoje emocje czy opisywać sytuacje dnia codziennego. Do podobnych wniosków doszłam także, przebywając $z$ polonijnymi dziećmi podczas wakacji $\mathrm{w}$ Polsce. Podczas zabaw $z$ polskimi kolegami miały one problemy $z$ nazywaniem przedmiotów i czynności. Brak słów wzbudzał w nich złość, ponieważ było to często przyczyną dziecięcych nieporozumień. Dlatego też w głównym etapie badań uwzględniłam komponent leksykalny, bez którego nie można ocenić kompetencji lingwistycznej. Próbki językowe oraz materiał ankietowy pokazały, że dzieci polskich emigrantów w USA miały problemy $z$ właściwym doborem jednostek leksykalnych $w$ różnych zakresach tematycznych. Radziły sobie ze standardowym słownictwem, np. nazwami części garderoby, lecz jeśli miały identyfikować przedmioty codziennego użytku, to pojawiały się problemy. W większości wypadków nie znały nazw nowoczesnych urządzeń powszechnie używanych w domach, nawet tych, których nazwy pochodziły $z$ języka angielskiego. Zaskakujace okazało się to, że nie dysponowały słownictwem zwiazanym $z$ technika komputerową. Niepokojącym spostrzeżeniem był brak umiejętności nazywania uczuć i emocji w języku polskim [Jędryka 2007; Jędryka 2012].

Przyglądając się wynikom pierwszych badań, zastanawiałam się nad przyczyna deficytów leksykalnych dzieci polonijnych. Odpowiedzi należało szukać wówczas w programach nauczania oraz $\mathrm{w}$ podręcznikach, $z$ których korzystali uczniowie i nauczyciele w szkołach. Przenalizowałam materiały do nauki języka polskiego i doszłam do wniosku, że należałoby je zmodyfikować pod względem leksykalnym. Niektórzy nauczyciele wykorzystywali nadal polski Elementarz Mariana Falskiego oraz podręczniki, których autorami byli przedstawiciele Polonii. Zauważyłam, że słownictwo, którego ucza, nie jest wystarczające, a w niektórych wypadkach nawet przestarzałe. Należało urozmaicić leksykę związana 
z przyrodą i życiem codziennym oraz zainteresowaniami. Materiały dydaktyczne powinny były zawierać słowa znane uczniom klas drugich w Polsce, aby odpowiednio wzbogacać słownik czynny i bierny ich polonijnych rówieśników.

Przeprowadzone w pierwszej dekadzie XXI wieku badania stały się dla mnie impulsem do podjęcia próby pogłębienia wiedzy na temat kompetencji leksykalnej większej grupy uczniów reprezentujących wszystkie klasy etapu dydaktyki wczesnoszkolnej - od pierwszej do trzeciej. Aby uzyskać lepszy obraz stanu słownika, którym dysponują najmłodsi użytkownicy polszczyzny poza krajem, do grupy uczniów ze Stanów Zjednoczonych dołaczyli ich rówieśnicy $z$ Ukrainy. W badaniach uwzględniono także dwie grupy kontrolne. Pierwsza stanowili uczniowie $z$ doświadczeniem migracji (UDM) w Polsce, dla których polszczyzna, pierwotnie język obcy, staje się z upływem czasu językiem edukacji. Druga grupa byli rodzimi użytkownicy języka. O zebraniu materiału porównawczego w pierwszej grupie kontrolnej zdecydowałam, ponieważ respondenci UDM maja zbliżona biografię językową do dzieci $z$ USA oraz Ukrainy, które nie maja polskiego pochodzenia, ale uczą się w języku polskim - języku edukacji.

Zbieranie próbek językowych trwało od 2018 do 2021 roku. W Stanach Zjednoczonych odbywało się to w mieście Nowy Jork, stanie New Jersey oraz w stanie Connecticut, a na Ukrainie w Iwano-Frankiwsku, dawnym Stanisławowie. Uczniowie $z$ ukraińskich szkół sobotnich byli także badani w Polsce tuż po swoim przyjeździe do nowego kraju. W badaniu uczestniczyło 370 respondentów, w tym 287 uczniów reprezentujaccych właściwa grupę badawczą oraz 83 dzieci w grupach kontrolnych. Materiał został pozyskany od 190 osób ze Stanów Zjednoczonych i od 97 z Ukrainy. Wśród respondentów należy wyróżnić dwie grupy dzieci, które były uczniami szkół $z$ polskim językiem wykładowym w obu krajach - 119 osób oraz uczniami szkół sobotnich - 168 osób.

Materiał badawczy został pozyskany w trakcie indywidualnych rozmów $z$ każdym uczestnikiem i był rejestrowany. W okresie wrzesień 2018-marzec 2020 spotkania $z$ uczniami odbywałam osobiście, jednak od kwietnia 2020 roku do kwietnia 2021 roku wszystko odbywało się $\mathrm{w}$ przestrzeni wirtualnej $z$ wykorzystaniem ZOOM, oprogramowania do spotkań online $z$ możliwościa rejestrowania. Zaistniała sytuacja badawcza była skutkiem pandemii koronawirusowej COVID-19, która uniemożliwiła mi bezpośredni kontakt $z$ uczniami na Ukrainie oraz niektórymi w Polsce. W sumie do analizy językowej zebrałam około 700 godzin nagrań.

Każdy z uczestników badań poddawany był tej samej procedurze, która składała się $z$ czterech elementów. Na początku respondent wchodził ze mną w interakcję językowa, majacca na celu wprowadzenie miłej i swobodnej atmosfery podczas zbierania materiału badawczego. Była to rozmowa dotyczaca zainteresowań ucznia, ostatnich wakacji, rodziny 
i przyjaciół. Następnie dziecko opisywało serie obrazków, na których przedstawiono różne scenki. Były także obrazki przedstawiające pojedyncze słowa - tzw. słowa w izolacji, pozbawione kontekstu sytuacyjnego. Czwartym elementem było snucie opowieści przez dziecko na podstawie sekwencji sześciu obrazków. Tak jak już zasygnalizowano we wstępie do niniejszego opracowania, badania zostały dostosowane do wieku i predyspozycji dzieci. $Z$ każdym $z$ nich spotykałam się od dwóch do trzech razy, aby pozyskać wystarczajaca próbkę językową.

Słownictwo, które zostało wyekscerpowane $z$ nagrań, poddano klasyfikacji. Tym razem wykorzystałam rozwiazanie zaproponowane przez Barbarę Batko-Tokarz, która podzieliła współczesne słownictwo języka polskiego na 7 sfer tematycznych, a w każdej $z$ nich wyodrębniła dodatkowo pola oraz podpola tematyczne. [Batko-Tokarz 2019]. Materiał leksykalny reprezentował każdą ze sfer, tj. człowiek jako istota fizyczna, człowiek jako istota psychiczna, codzienne życie człowieka, człowiek w społeczeństwie, człowiek i technika, człowiek i przyroda oraz kategorie fizyczne. Ponieważ badania były przeprowadzone wśród dzieci, nie wszystkie pola oraz podpola w każdej ze sfer zostały wypełnione. Jest to zwiąane nie tylko ze znajomościa polszczyzny, ale przede wszystkim $z$ rozwojem umysłowym człowieka na tym etapie życia. W celu upewnienia się, czy dziecko dysponuje daną jednostką leksykalną w swoim rodzimym języku, pytałam o nia podczas przeprowadzania wywiadu oraz rozmów kończących spotkania. Dzięki temu uzyskałam pewność, że to nie niski poziom kompetencji leksykalnej w obszarze polszczyzny stanowi problem w komunikacji, ale brak elementów wiedzy o świecie w języku prymarnym.

Po wstępnych pracach nad materiałem widać, że uczniowie $z$ obu krajów mają deficyty językowe w różnych zakresach tematycznych. Niektóre $z$ nich sa charakterystyczne tylko dla uczniów ze szkół sobotnich, a inne dla dzieci uczących się w języku polskim. Można także wyróżnić luki leksykalne, które sa typowe dla dzieci najmłodszych pochodzących z poszczególnych obszarów badawczych. Oczywiście istnieja także takie braki w słownictwie, które są wspólne dla wszystkich respondentów. Niniejsze opracowanie prezentuje zakresy tematyczne o największym niedoborze leksykalnym wspólne dla wszystkich respondentów, zarówno tych uczacych się polszczyzny w systemie sobotnim, jak i tych uczacych się w systemie dwujęzycznym.

Zebrany materiał leksykalny został przedstawiony w formie tabel (nr 1-7). Każda tabela reprezentuje jedna ze sfer i zawiera pola oraz podpola, w których odnotowano największe deficyty w słowniku uczniów z Ukrainy i ze Stanów Zjednoczonych. Dodatkowo zaprezentowano po kilka przykładowych leksemów dla każdego podpola oraz podano ich wartość procentową obrazująca odsetek respondentów, którzy wykazali się nieznajomościa danego wyrazu w stosunku do grupy kontrolnej reprezentowanej przez rodzimych użytkowników języka w Polsce. 

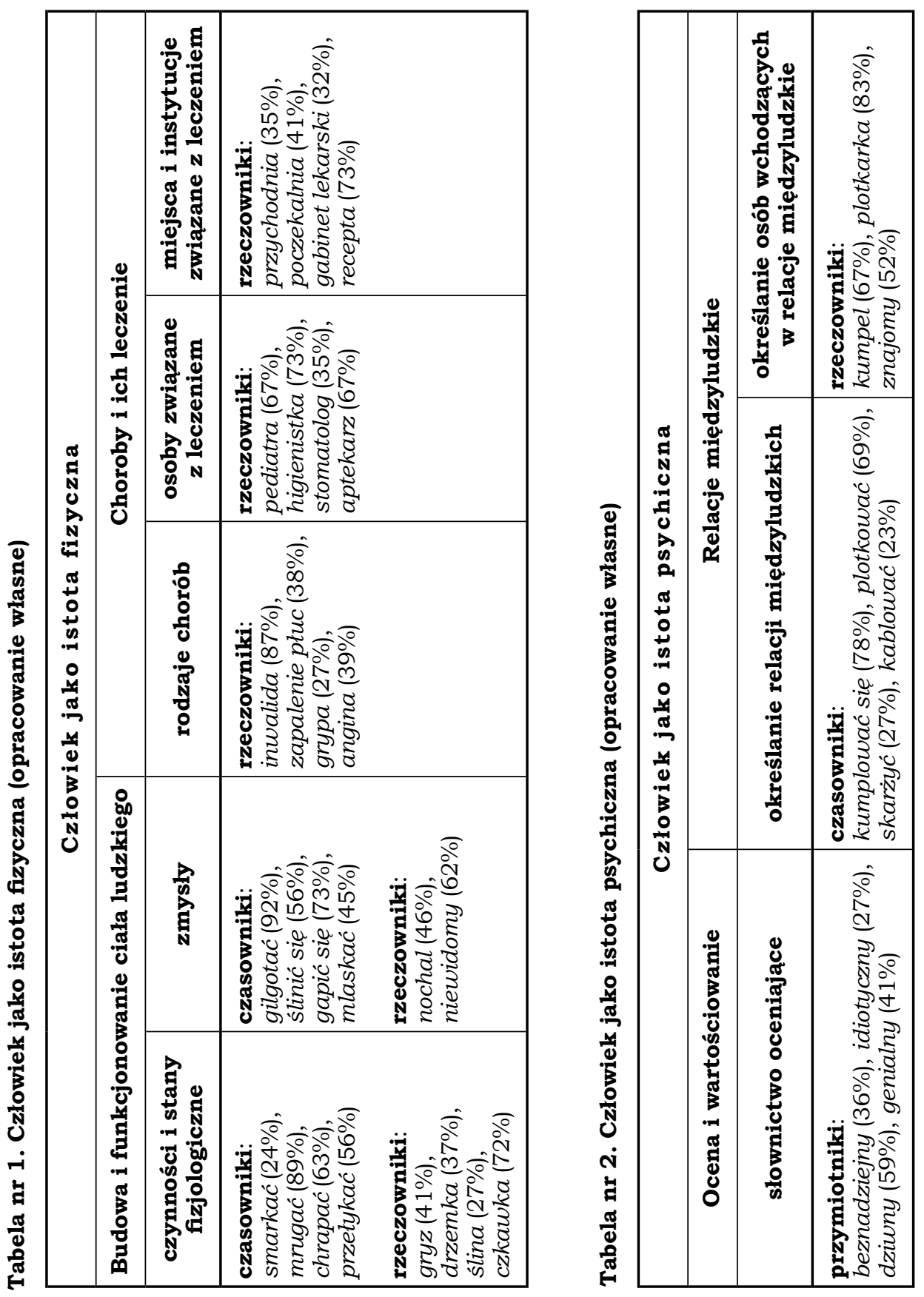

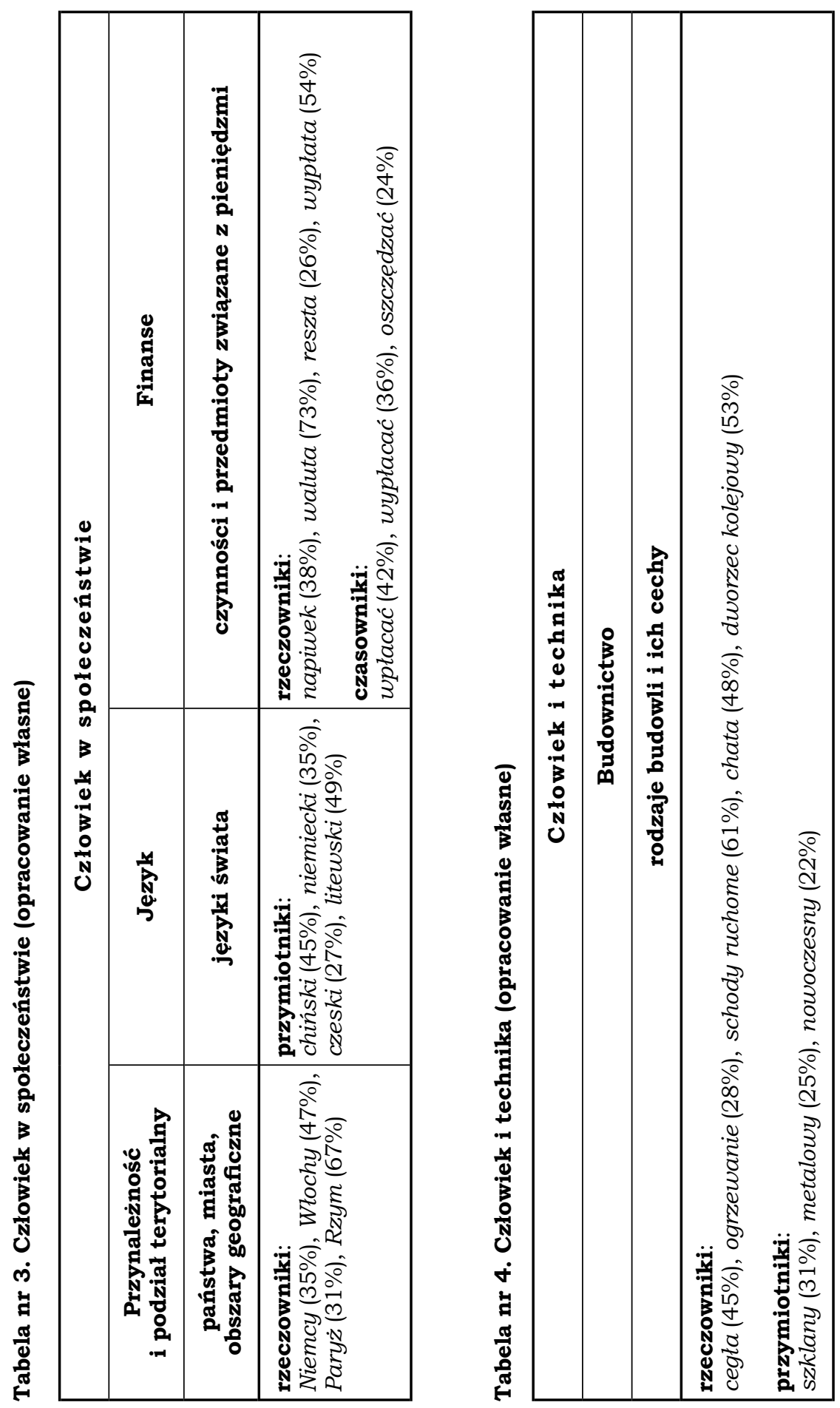

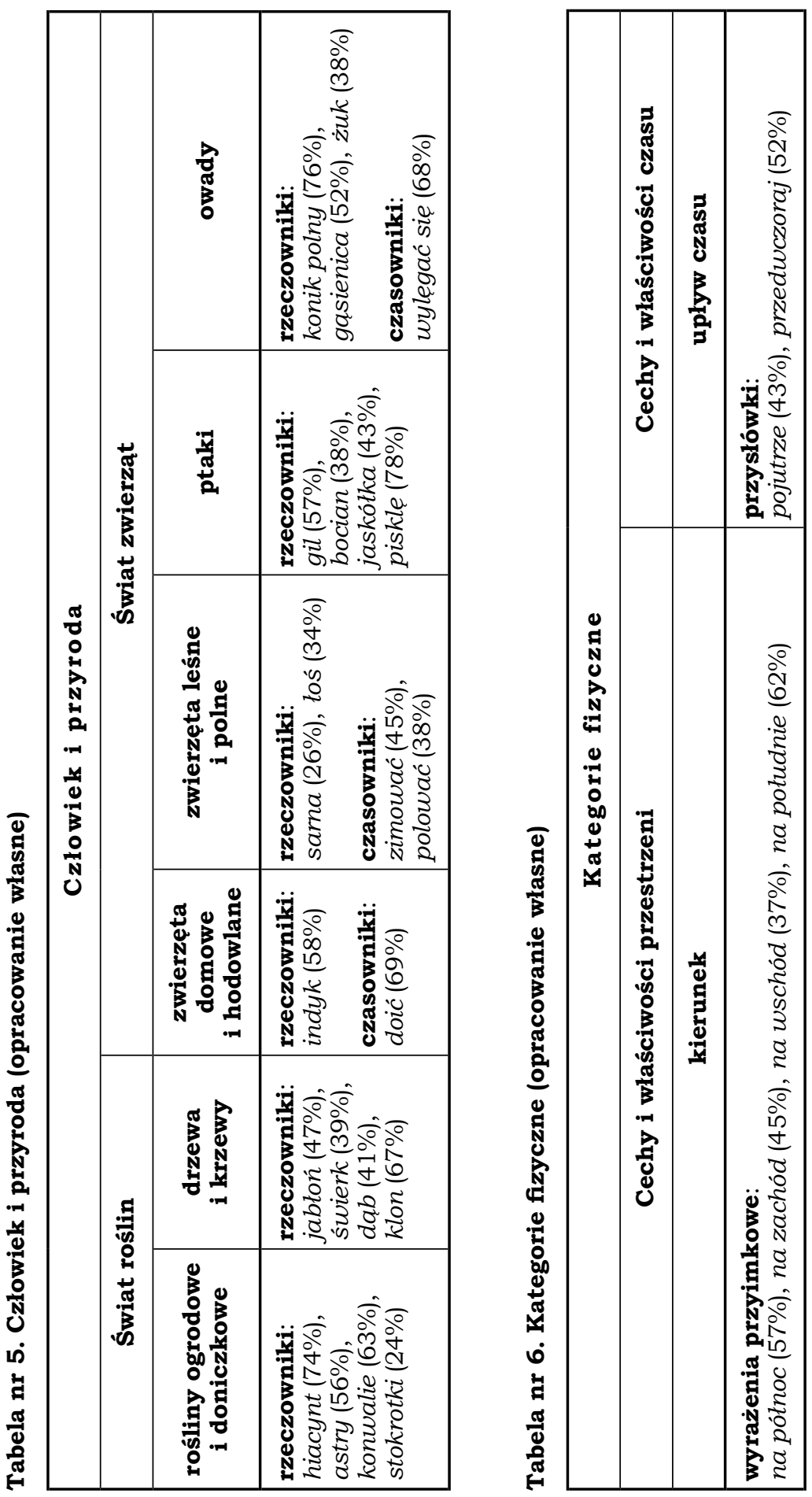


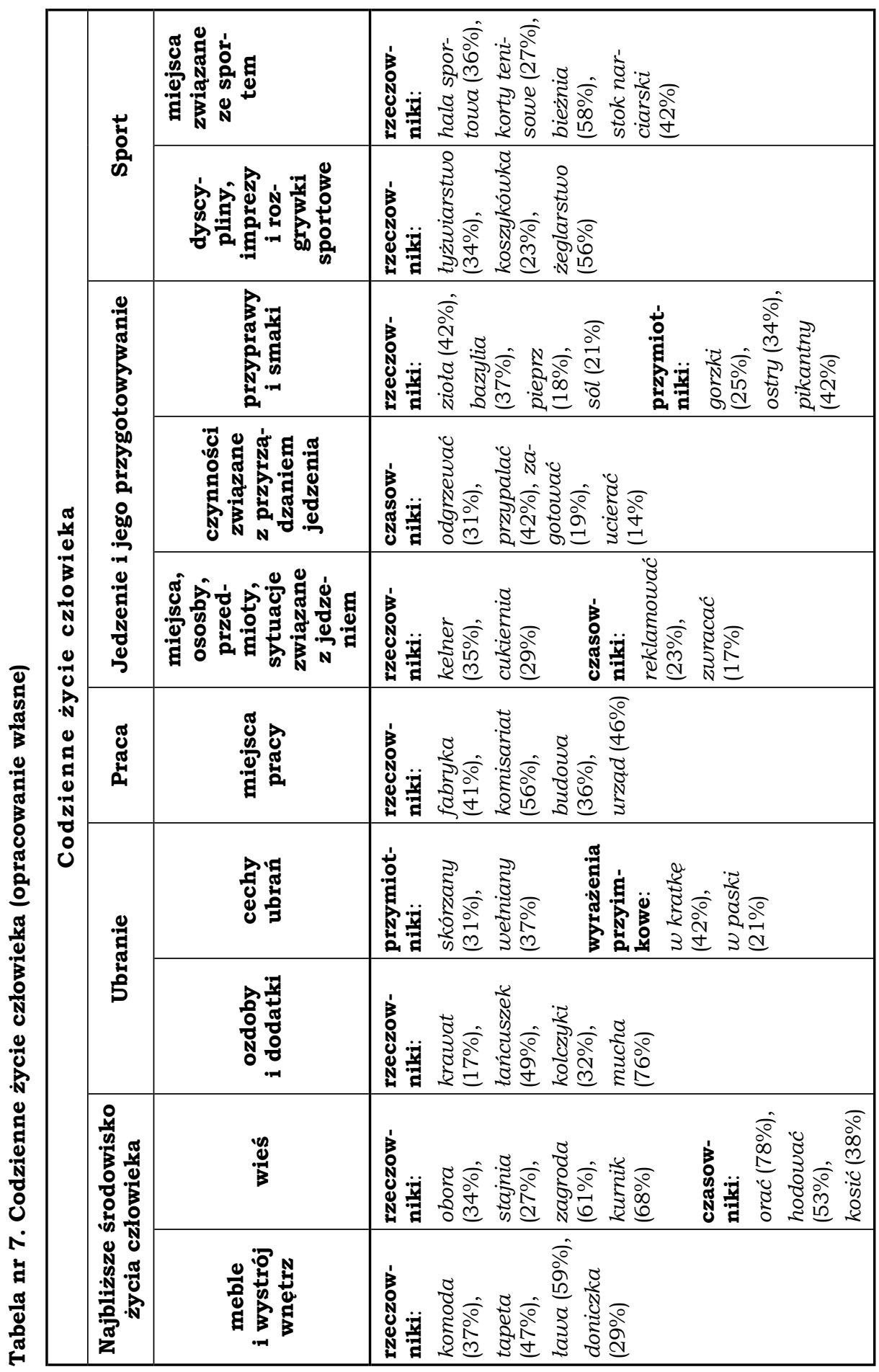


Powyższa próbka materiału badawczego oraz jego wstępna analiza pokazuje, że rozwój leksykalny respondentów jest uzależniony przede wszystkim od odpowiedniej stymulacji językowej, która otrzymuja uczniowie $z$ dwóch źródeł - domu oraz szkoły. Pierwsze $z$ nich rozwija słownictwo $z$ zakresu codziennego życia człowieka, człowieka jako istoty fizycznej oraz psychicznej. Niestety „użytkowy” leksykon rodziców oraz osób posługujących się językiem polskim w otoczeniu dziecka jest ograniczony, ponieważ sytuacje komunikacyjne, w których najczęściej się znajduja, sa powtarzalne oraz nie wymagają używania dużego zasobu słów od ich uczestników. Dodatkowo dzieci w wieku wczesnoszkolnym rzadziej sa wspierane dydaktycznie przez rodziców, którzy ciężar edukacji językowej przenoszą na szkołę - drugie źródło rozwijajacce słownik czynny oraz bierny dzieci. Zajęcia językowe w szkole wzbogacaja słownictwo $z$ zakresów: człowiek w społeczeństwie, człowiek i technika, człowiek i przyroda oraz kategorie fizyczne. Jednak nauczyciele, prowadzacy zajęcia w szkołach sobotnich, bez współpracy z rodzicami nie mają szans na właściwe rozwijanie zasobu leksykalnego dzieci. Ogranicza ich wymiar zajęć oraz materiały dydaktyczne. W lepszej sytuacji językowej sa uczniowie klas dwujęzycznych, którzy codziennie zanurzają się w polszczyźnie i mają szansę na częstsze używanie nowo poznanych słów.

Deficyty słownikowe uczniów na Ukrainie i w USA w porównaniu z zasobem leksykalnym ich rówieśników w Polsce mają złożoną przyczynę. Można rozpatrywać je indywidualnie w kontekście każdego uczestnika badania oraz w kontekście grupowym - dzieci w wieku wczesnoszkolnym, które uczą się w języku polskim. W moich badaniach jestem zainteresowana przede wszystkim tym drugim kontekstem, ponieważ pozyskane dane językowe powinny być podstawa tworzenia programów oraz materiałów dydaktycznych dla uczniów poza granicami Polski, które do tej pory sa przygotowywane na podstawie intuicji autorów. Dodatkowo powinna być uwzględniana wiedza $z$ zakresu psycholingwistyki dotycząca budowania słownika dzieci dwujęzycznych. Dobrze skonstruowane podręczniki dla etapu wczesnoszkolnego pod względem leksyki są szansą na to, że uczniowie będą mieli możliwość właściwego rozwijania swojego słownictwa $z$ wszystkich zakresów współczesnej polszczyzny.

Odnotowane braki leksykalne uczniów ze szkół w Stanach Zjednoczonych zostały uwzględnione podczas opracowywania podręcznika oraz zeszytu ćwiczeń Polskie niezapominajki do nauki języka polskiego jako odziedziczonego w klasach I-III. Materiał powstał w 2019 roku na potrzeby szkolnictwa polonijnego na Wschodnim Wybrzeżu Stanów Zjednoczonych. W roku szkolnym 2020/2021 były wykorzystywane $\mathrm{w}$ pierwszych i drugich klasach w szkołach zrzeszonych w CPSD. Na spotkaniach $z$ nauczycielami, podsumowujących pracę $z$ podręcznikiem, niejednokrotnie informowano zespół autorski, że dzieci bardzo dobrze przyjeły podręcznik. Pedagodzy pracujący w klasach drugich odnotowali przyrost leksykalny wśród swoich uczniów. Wydawca Polskich niezapo- 
minajek - Fundacja na rzecz Wspierania i Rozwoju Szkół Polonijnych otrzymała także sygnały, że podręcznik sprawdza się w pracy $z$ dziećmi na Ukrainie. Można to potraktować jako potwierdzenie tezy, że warto badać leksykę w dydaktyce najmłodszych użytkowników polszczyzny poza krajem.

\section{PODSUMOWANIE}

Moje wstępne badania przeprowadzone w Stanach Zjednoczonych, na Ukrainie i w Polsce pokazały, że istnieje wyraźna potrzeba analizy leksykonu uczniów młodszych klas szkół podstawowych poza granicami Polski, którzy uczą się języka w różnych uwarunkowaniach środowiskowych. Edukacja na etapie wczesnoszkolnym stanowi podstawę dalszej nauki. Braki leksykalne w konkretnych obszarach tematycznych hamuja rozwój językowy uczniów.

Po pierwsze, ich wyniki powinny być wykorzystane do tworzenia nowych programów kształcenia językowego, które odpowiadałyby na faktyczne potrzeby nazywania przez dzieci dynamicznie zmieniajacej się rzeczywistości. Po drugie, na podstawie materiału językowego, także porównawczego, warto opracować inwentarz leksykalny, stanowiący punkt wyjścia opracowania nowych materiałów dydaktycznych, w tym podręczników. Listy wyrazowe, zawierające jednostki, którymi powinien posługiwać się uczeń kończący etap edukacji wczesnoszkolnej, pomocne byłyby także w opracowywaniu testów diagnostycznych, plasujących oraz biegłości, pod względem leksykalnym, którymi dziś niestety nie dysponują nauczyciele.

\section{Bibliografia}

C. Baker, W.E. Wright, 2017, Foundations on Bilingual Education and Bilingualism, Bristol.

B. Batko-Tokarz, 2019, Tematyczny podział słownictwa współczesnego języka polskiego - teoria, praktyka, leksykografia, Kraków.

A. Brzozowska-Krajka, 2017, „Nie domy sie ...”: gwarowa odmiana polszczyzny jako marker grupowej tożsamości kulturowej $w$ wieloetnicznej Ameryce ( $w$ świetle działalności Zwiazku Podhalan Północnej Ameryki) [w:] M. Lachowicz, K. Polasik-Wrzosek (red.), Język polski jako nośnik tożsamości, Poznań, s. $121-139$.

M. Belokoneva-Shiukashvili, 2017, Język polski jako wartość w życiu Polonii gruzińskiej [w:] M. Lachowicz, K. Polasik-Wrzosek (red.), Język polski jako nośnik tożsamości, Poznań, s. 37-45.

K. Błaszczuk, 2017, Międzypokoleniowy przekaz tożsamości kulturowej [w:] M. Lachowicz, K. Polasik-Wrzosek (red.), Język polski jako nośnik tożsamości, Poznań, s. 175-188. 
J. Cieszyńska, 2006, Dwujęzyczność, dwukulturowość-przekleństwo czy bogactwo? O poszukiwaniu tożsamości Polaków w Austrii, Kraków.

A. Czeniek, 2010, Stosunek uczniów Polskich Szkół Sobotnich w Wielkiej Brytanii do sprawności pisania, „Poradnik Językowy” z. 2, s. 84-96.

A. Czeniek, 2011, Rola wypracowań dzieci polskiego pochodzenia $w$ badaniach nad stopniem opanowania języka, „Acta Universitatis Lodziensis - Kształcenie Polonistyczne Cudzoziemców” t. 18, s. 353-363.

A. Czeniek, 2014, Jedna szkoła, jedna klasa, ale czy ten sam język polski? o zróżnicowanym poziomie opanowania języka polskiego wśród dzieci polskiego pochodzenia na przykładzie prac dzieci mieszkajacych $w$ Wielkiej Brytanii, „Poradnik Językowy” z. 4, s. 54-68.

A. Czeniek, 2015, Język polski mniej lub bardziej dziedziczony. Czynniki wpływające na kompetencję językowa dzieci polskich emigrantów, „Poradnik Językowy" z. 8, s. 90-100.

S. Dubisz, 1997a, Społeczne role polszczyzny poza granicami kraju. Pamięci Profesora Mieczysława Szymczaka [w:] B. Janowska, J. Porayski-Pomsta (red.), Język polski w kraju i za granica, t. I, Warszawa, s. 17-20, Warszawa.

S. Dubisz, 1997b, Typologia odmian polszczyzny poza granicami kraju [w:] B. Janowska, J. Porayski-Pomsta (red.), Język polski $w$ kraju i za granica, t. I, Warszawa, s. 35-42.

S. Dubisz, 1997c, Język polski poza granicami kraju-wstępne informacje $i$ definicje [w:] S. Dubisz (red.), Język polski poza granicami kraju, Opole, s. 13-46.

S. Dubisz, E. Sękowska, 1990, Typy jednostek leksykalnych w socjolektach polonijnych (próba definicji i klasyfikacji) [w:] W. Miodunka (red.), Język polski $w$ świecie, Warszawa-Kraków, s. 217-233.

J.A. Fishman, 1998, Language and Ethnicity: The View from Within [w:] F. Coulmas (red.), The Handbook of Sociolinguistics, Oxford, s. 327-343.

J.A. Fishman, 1999, Handbook of Language and Ethnic Identity, Oxford.

J.A. Fishman, 2001, 300-Plus Years of Heritage Language Education in the United States [w:] J. Kreeft Peyton, D.A. Ranard, S. McGinnis (red.), Heritage Languages in America. Preserving a National Resource, McHenry, s. 81-99.

K. Geben, 2003, Świadomość i kompetencja językowa, a warstwy leksykalne widiolektach młodzieży polskiego pochodzenia na Wileńszczyźnie, Warszawa.

S. Günthner, 2017, Doing Culture - kulturowa samoidentyfikacja i identyfikacja innych $w$ rozmowie [w:] W. Czachur (red.), Lingwistyka kulturowa i międzykulturowa. Antologia, Warszawa, s. 187-214.

I. Janowska, E. Lipińska, A. Rabiej, A. Seretny, P. Turek, 2016, Programy nauczania języka polskiego jako obcego. Poziomy A1-C2, Kraków.

B.K. Jędryka, 2007, Brak mi słów - problemy leksykalne dzieci polonijnych $w U S A$, „Prace Filologiczne” t. 52, s. 133-140.

B.K. Jędryka, 2014, Status języka polskiego jako drugiego i obcego w polskiej szkole, „Poradnik Językowy” z. 10, s. 42-53.

B.K. Jędryka, 2015, Metodyka nauczania języka polskiego jako obcego / drugiego dzieci $w$ wieku przedszkolnym, Warszawa.

B.K. Jędryka, 2017, Szkolnictwo polonijne w Stanach Zjednoczonych - wczoraj i dziś [w:] B.K. Jędryka, E. Kwapień (red.), W labiryncie polszczyzny - Profesorowi Stanisławowi Dubiszowi - doktorzy i doktoranci, Warszawa, s. 317-329.

B.K. Jędryka, 2012, Język polski w polonijnej szkole. Na przykładzie badań przeprowadzonych $w$ Clark - New Jersey, USA, Warszawa. 
H. Karaś, 1997a, Uwagi o sytuacji języka polskiego na Łotwie [w:] B. Janowska, J. Porayski-Pomsta (red.), Język polski w kraju i za granica, t. I, Warszawa, s. $52-61$.

H. Karaś, 1997b, Język polski na Łotwie [w:] S. Dubisz (red.), Język polski poza granicami kraju, Opole, s. 69-78.

H. Karaś, 2015, Odrodzenie polszczyzny czy jej zanik? O sytuacji języka polskiego na dawnych Kresach Wschodnich, „Poradnik Językowy” z. 8, s. $18-35$.

A. Krawczuk, 2019, Świadomość językowa osób polskiego pochodzenia na Ukrainie $w$ zakresie używania wybranych form grzecznościowych, „Rozprawy Komisji Językowej" t. 67, s. 173-190.

A. Krawczuk, J. Kowalewski, 2017, Metodyka nauczania języka polskiego. Język i kultura $w$ dydaktyce polonistycznej na Ukrainie. Podręcznik dla szkót wyższych, Kijów.

K. Kuros-Kowalska, 2020, Metody stymulowania rozwoju słownictwa w języku polskim u dzieci dwujęzycznych na emigracji, Katowice.

R. Laskowski, 2009, Język w zagrożeniu. Przyswajanie języka polskiego w warunkach polsko-szwedzkiego bilingwizmu, Kraków.

P. Levchuk, 2020, Trójjęzyczność ukrainsko-rosyjsko-polska Ukrainców niepolskiego pochodzenia, Kraków.

A. Libura, 2014, Atrycja języka odziedziczonego [w:] A. Dąbrowska, U. Dobesz (red.), 40 lat wrocławskiej glottodydaktyki polonistycznej. Teoria i praktyka, Wrocław, s. 303-312.

A. Libura, A. Żurek, 2016, Erozja dopełniacza w polskim języku odziedziczonym, „Poradnik Językowy” z. 2, s. 38-49.

A. Libura, A. Żurek, 2018, Jak będa mówić dzieci osób, które dziś emigruja z Dolnego Ślaska? Badania nad polszczyzna osób dwujęzycznych [w:] A. Tworek (red.), Germanistyka otwarta. Wrocławskie debaty o języku i językoznawstwie, Wrocław, s. 142-163.

E. Lipińska, A. Seretny, 2012, Między językiem ojczystym a obcym. Nauczanie $i$ uczenie się języka odziedziczonego na przykładzie chicagowskiej diaspory polonijnej, Kraków.

K. Liebkind, 1999, Social psychology [w:] J.A. Fishman (red.), Handbook of language and social identity, New York, s. 140-151.

E. Lipińska, A. Seretny, 2012a, Między językiem ojczystym a obcym. Nauczanie $i$ uczenie sie języka odziedziczonego na przykładzie szkolnictwa polonijnego $w$ Chicago, Kraków.

E. Lipińska, A. Seretny, 2012b, Szkoła polonijna czy językowa? Szkolnictwo polonijne w perspektywie dydaktycznej, „Studia Migracyjne - Przegląd Polonijny” t. 38, nr 4(146), s. 23-37.

E. Lipińska, A. Seretny, 2016a, Polish as a heritage language-somewhere in between, „Studia Migracyjne - Przegląd Polonijny” nr 2, s. 177-201.

E. Lipińska, A. Seretny, 2016b, Język odziedziczony-polszczyzna pokoleń polonijnych, „Poradnik Językowy” z. 10, s. 45-61.

B. Maliszewski, 2020, Uczyć sie „od błędów” - analiza uchybień $w$ pisemnych pracach uczniów szkół polonijnych w USA, „Półrocznik Językoznawczy Tertium. Tertium Linguistic Journal" 5, s. 211-232.

A. Masiewicz, 1990, Język Polonii francuskiej [w:] W. Miodunka (red.), Język polski w świecie, Warszawa-Kraków, s. 199-216. 
A. Mielczarek, B. Walczak, 2017, W jakim stopniu język stanowi o tożsamości narodowej? [w:] M. Lachowicz, K. Polasik-Wrzosek (red.), Język polski jako nośnik tożsamości, Poznań, s. 13-22.

W. Miodunka, 1990a, Język a identyfikacja kulturowa i etniczna. Studium ksztattowania się tożsamości rodzeństwa należacego do drugiego pokolenia Polonii australijskiej [w:] W. Miodunka (red.), Język polski w świecie, WarszawaKraków, s. 105-125.

W. Miodunka, 1990b, Moc języka i jej znaczenie w kontaktach językowych $i$ kulturowych [w:] W. Miodunka (red.), Język polski w świecie, Warszawa-Kraków, s. 39-49.

W. Miodunka, 2016, Glottodydaktyka polonistyczna. Pochodzenie - stan obecny - perspektywy, Kraków.

I.A. NDiaye, 2016, Uwarunkowania językowe emigrantów rosyjskich pierwszej fali i poszukiwanie własnej tożsamości $w$ nowym otoczeniu kulturowym [w:] W. Stec, A. Hau (red.), W poszukiwaniu tożsamości językowej, t. II, Gdańsk, s. $15-33$.

A. Padilla, 1999, Psychology [w:] J.A. Fishman (red.), Handbook of language and social identity, New York, s. 109-121.

M. Pamuła-Behrens, 2018, Język edukacji szkolnej $w$ integracyjnym modelu wsparcia ucznia $z$ doświadczeniem migracji $w$ rodzinie, „Postscriptum Polonistyczne" nr 2, s. 171-186.

M. Pamuła-Behrens, M. Szymańska, 2018a, Metodyka nauczania języka edukacji szkolnej uczniów z doświadczeniem migracji. Metoda JES-PL. Matematyka, Kraków.

M. Pamuła-Behrens, M. Szymańska, 2018b, Metoda JES-PL. Nauczanie uczniów $z$ doświadczeniem migracji, „Języki Obce w Szkole” nr 2, s. 4-10.

M. Piasecka, 2016, Język polski $w$ Norwegii. Na przykładzie badań przeprowadzonych $w$ polskich szkołach $w$ Oslo, Warszawa.

H. Pułaczewska, 2017, Wychowanie do języka polskiego w Niemczech na przykładzie Ratyzbony, Łódź.

A. Rabiej, 2006, Irlandia po polsku - nowy język na Zielonej Wyspie [w:] K. Gąsowska, M. Mazińska-Szumska (red.), Oświata polonijna na poczatku XXI wieku. Stan i perspektywy, Kraków, s. 149-157.

A. Rabiej, 2008, Postawy i preferencje językowe młodszych uczniów szkół polonijnych [w:] W.T. Miodunka, A. Seretny (red.), W poszukiwaniu nowych rozwiazań. Dydaktyka języka polskiego jako obcego u progu XXI wieku, Kraków, s. 481-490.

A. Rabiej, 2013, Co motywuje i demotywuje dzieci do nauki języka polskiego za granica, „Języki Obce w Szkole” nr 3, s. 48-53.

G. Rappaport, 1990, Sytuacja językowa Amerykanów polskiego pochodzenia $w$ Teksasie [w:] W. Miodunka (red.), Język polski w świecie, Warszawa-Kraków, s. 159-178.

P. Riley, 2007, Introduction [w:] Language, culture and identity: an ethnolinguistic perspective, London, s. 1-20.

J. Sadowska, 2017, Polacy i język polski $w$ Republice Buriacji [w:] M. Lachowicz, K. Polasik-Wrzosek (red.), Język polski jako nośnik tożsamości, Poznań, s. $47-61$.

U. Schmidt, 2008, Language Loss and the Ethnic Identity of Minorities, Flensburg. 
A. Seretny, 2011, Kompetencja leksykalna uczacych sie języka polskiego jako obcego w świetle badań ilościowych, Kraków.

A. Seretny, 2015, Słownictwo $w$ dydaktyce języka. Świat słów na przykładzie języka polskiego jako obcego, Kraków.

A. Seretny, 2018, Język szkolnej edukacji w perspektywie glottodydaktycznejzarys problematyki, „Postscriptum Polonistyczne” nr 2, s. 139-156.

E. Sękowska, 2010, Język emigracji polskiej w świecie. Bilans i perspektywy badawcze, Kraków.

J.J. Smolicz, 1990, Język jako wartość podstawowa kultury [w:] W. Miodunka (red.), Język polski w świecie, Warszawa-Kraków, s. 23-38.

H. Sokołowska, 2004, Wielojęzyczność a umiejętności komunikacyjne uczniów szkót polskich na Litwie, Warszawa-Wilno.

N. Szumlańska, 2013, Sytuacja języka polskiego na Ukrainie, „Poradnik Językowy" z. 8, s. 33-48.

A. Szybura, 2016, Nauczanie języka polskiego dzieci imigrantów, migrantów i reemigrantów, „Języki Obce w Szkole” nr 1, s. 112-117.

A. Tabouret-Keller, 1998, Language and Identity [w:] F. Coulmas (red.), The Handbook of Sociolinguistics, Oxford, s. 315 - 326.

P. Wichniewicz, 2017, Powroty. Polska mniejszość narodowa w Ćelinovacu, Bośnia i Hercegowina [w:] M. Lachowicz, K. Polasik-Wrzosek (red.), Język polski jako nośnik tożsamości, Poznań, s. 107-120.

H. Zgółkowa, Dobór słownictwa w nauczaniu języka polskiego jako obcego [w:] W. Miodunka (red.), Język polski jako obcy. Programy nauczania na tle badan współczesnej polszczyzny, Kraków, s. 37-104.

A. Żurek, 2018, Strategie komunikacyjne osób dwujęzycznych. Na przykładzie polszczyzny odziedziczonej $w$ Niemczech, Kraków.

\title{
O potrzebie badania kompetencji leksykalnej dzieci $w$ wieku wczesnoszkolnym $w$ dydaktyce języka polskiego za granica (na przykładzie Stanów Zjednoczonych i Ukrainy)
}

\author{
Streszczenie
}

Znajomość słownictwa dzieci w wieku wczesnoszkolnym uczących się języka polskiego poza granicami Polski jest jednym $z$ najważniejszych wyznaczników poziomu opanowania polszczyzny. W artykule przedstawiono sytuację dydaktyki polszczyzny w Stanach Zjednoczonych i na Ukrainie. Dodatkowo został omówiony status języka wśród osób polskiego pochodzenia. Autorka opisuje wstępne wyniki badań kompetencji leksykalnej uczniów - zakresy tematyczne, w których odnotowano największy deficyt słownikowy dzieci w porównaniu $z$ ich rówieśnikami w Polsce.

Słowa klucze: język polski - język edukacji - język odziedziczony kompetencja leksykalna - dydaktyka języka - polszczyzna poza krajem. 


\section{The need to research the lexical competence of early school-age children in Polish language teaching abroad (on the example of the United States of America and Ukraine)}

\section{Summary}

The knowledge of the vocabulary of early school-age children learning Polish abroad is one of the most important determinants of the level of their language proficiency. The paper presents the situation of Polish language teaching in the United States of America and Ukraine. Additionally, the paper discusses the status of the language among people of Polish origin. The author describes the preliminary results of the research on lexical competence of students: semantic fields with the largest lexical deficit among the children compared to their peers in Poland.

Keywords: Polish language - language of education - heritage language lexical competence - language teaching - Polish abroad.

Adj. Monika Czarnecka 